evidence is competent, it surely can be indicative of nothing more than the fact that twelve men, judging the same facts by a different standard, decided that the defendant was not guilty of a particular crime. When the fact-finders are satisfied as to the licensee's guilt or misbehavior from other evidence, are they to disregard the fact of rendition, or should they change their finding as a result of it? Either choice involves a speculation as to what the jury would have done if not restricted by the reasonable doubt rule. This task is in its nature impossible. The evidence has no relevance beyond that which the fact-finders choose to give it. On the other hand, where the prior judgment was a conviction, the fact of rendition may have a legitimate evidentiary use. Where not in itself a ground for revocation, the conviction may be relevant to such statutory grounds for revocation as professional misconduct or commission of a crime involving moral turpitude. ${ }^{37}$

In conclusion, prior criminal acquittals have a limited relevance in license revocation proceedings, but convictions have considerably more relevance. Nevertheless, in both situations there are theoretical and practical objections to the use of res judicata which override its salutary policy of diminishing litigation. Convictions may be relevant as evidence, but admitting evidence of the rendition where the licensee has been acquitted has no utility beyond allowing the fact-finders a discretionary power to give the acquittal a conclusive effect. The latter practice would lead to uneven and uncertain-and hence undesirable -results.

${ }^{27}$ Refer to note 33 supra.

\title{
THE ROLE OF THE JUDICIAL SALE IN PREVENTING UNECONOMICAL PARCELLATION OF INHERITED LAND
}

For over one hundred years it has been the general rule in the United States that intestate property descends equally to the decedent's children, subject to the rights of the surviving spouse. ${ }^{1}$ Developed largely in response to democratic ideals of equality ${ }^{2}$ and dignity of ownership, ${ }^{3}$ partible inheritance has been increasingly criticized in modern times. Proponents of land reform claim that parcellation, especially of agricultural land, ${ }^{4}$ among several heirs through suc-

${ }^{1}$ Consult, for a brief survey, Wypyski, The Law of Inheritance (Legal Almanac Series, 1953).

2 See Rheinstein, Cases on Decedents' Estates 28 (2d ed., 1955).

3 Sayre, Recent Ideologies in the Law of Succession to Property, 32 Ill. L. Rev. 691, 693 (1938). For discussions on the beginnings of partible inheritance in the United States consult Haskins, The Beginnings of Partible Inheritance in the American Colonies, 51 Yale L. J. 1280 (1942); Morris, Primogeniture and Entailed Estates in America, 27 Col. L. Rev. 24 (1927).

- It has been estimated that five out of six farmers die intestate. Johnson and Barlowe, Land Problems and Policies 287 (1954). 
ceeding generations causes land to be broken up into uneconomic units; ${ }^{5}$ that is, farms will become too small ${ }^{6}$ to be capable of efficient utilization. ${ }^{7}$

The general problem of parcellation is recognized as acute in many parts of the world. ${ }^{8}$ In France, particularly, the unduly small size of farm holdings has been attributed directly to her system of equal inheritance. ${ }^{9}$

It is the purpose of this comment to demonstrate the extent to which, in the United States, compulsory judicial sales may effectively prevent any undue fragmentation of land $\mathrm{d}^{10}$ resulting from our system of partible inheritance, in

${ }^{5}$ Such criticism is not uncommon in the United States. In a Department of Agriculture publication it was said that "[t]he philosophy of distributing the property equally among the several heirs . . . has resulted in subdivision into uneconomic-sized units." U.S. Dep't Agriculture, Soils and Men, Yearbook of Agriculture 117 (1938). Specific reference was here made to the southern Appalachian highlands and parts of Utah and eastern Idaho. De Tocqueville, in discussing America, remarked that where there is equality of division, land has a "permanent tendency to decrease." 1 De Tocqueville, Democratie en Amerique 57-58 (13th ed., 1850) (Reeve trans., 1945). Contrast Wedgwood, The Economics of Inheritance 73-74 (1929).

- According to the 1950 census the average United States farm was 215.3 acres, a considerable increase from the average farm of 146.2 acres in 1900 . The figures are somewhat misleading for purposes of the criticism of partible inheritance, inasmuch as in 1950 nine per cent of American farms were less than ten acres in area, and one quarter of the farms were less than thirty acres. The figures are set out in Johnson and Barlowe, op. cit. supra note 4, at 291.

${ }^{7}$ It has also been argued that farms held by several heirs are subject to poor maintenance because of the difficulty of obtaining agreement upon expenditures (Diller, Farm Ownership, Tenancy, and Land Use in a Nebraska Community 54 [1941]) and because the use of machinery is rendered difficult (Charmont, Changes of Principle in the Field of Family, Inheritance, and Persons, in Progress of Continental Law in the Nineteenth Century 147, XI Continental Legal History Series [1918]). Charmont however does not fully agree with this argument.

It has also been suggested that partible inheritance has contributed to an excessive amount of farm tenancy. In 1950,26.8 per cent of American farms were operated by tenants and 18.3 per cent of American farm land was tenant operated. Johnson and Barlowe, op. cit. supra note 4 , at 259,260 . However, the statistics are misleading and the criticism speculative. Relatively little tenancy is permanent; most tenancy occurs when a farmer leases land, often from a relative, as the first step towards obtaining ownership. Cf. Kolb and Brunner, A Study of Rural Society 316 (1935). Consult, also, Rheinstein, Cases on Decedents' Estates 33 (2d ed., 1955). Furthermore, the amount of tenancy prevailing at any given time is largely dependent on the level of farm income at that time. The amount of tenancy reached its peak during the depression years, and when farm income runs high it is possible for many tenants to become owners. For one view defending tenancy consult Johnson and Barlowe, supra, at 274.

${ }^{8}$ Consult United Nations Secretariat, Land Reform-Defects in Agrarian Structure as Obstacles to Economic Development 6-7 (1951). Here the small size of farm holdings is said to be the outstanding feature of the agrarian structure in many agriculturally under-developed countries, particularly in Asia and Africa. In these areas, however, there are operating serious factors of population pressure and unequal distribution of land ownership.

- Sayre, op. cit. supra note 3 , at 693.

${ }^{10}$ Elsewhere in the world land reform measures have been utilized, most striking of which was the Nazi peasant land law. Large German estates had been split up into ineffective plots largely because of equal inheritance. Generally, under the reform law, the peasant land holding was inherited only by such heir who undertook to farm the land advantageously. Failing efficient cultivation, a forced sale was made to some person or persons, heirs or not, who were adjudged capable of using the property worthily through a system of bureaucratic findings. Sayre, op. cit. supra note 3, and for a very extensive study, Kaden, The Peasant Inheritance Law in Germany on the Basis of the Reich's Hereditary Peasant Farm Law of 1933, 20 Iowa I. Rev. 350 (1935). The law was repealed by Control Council Law No. 45 of February 20,1947. Furthermore, in France the heirs have an option to refuse physical par- 
spite of a general statutory preference for partition in kind.11

The remedy of compulsory judicial partition of property is available in all states to owners of undivided shares of real property, thereby enabling them to sever their interests. ${ }^{12}$ Partition may be granted either in specie or by sale of the property and division of the proceeds. ${ }^{13}$ In every state but one ${ }^{14}$ a statutory preference exists in favor of partition in kind, which will be granted as a matter of right, while the party who seeks a sale must prove the necessity for it. By such physical division an owner is permitted to hold, enjoy, and improve his separate interest at his own will, and any difficulties or injuries likely to result from common undivided possession are removed..$^{15}$ Moreover, courts have indicated in the strongest possible language a preference for partition in kind ${ }^{16}$ both because the existing form of inheritance is not disturbed ${ }^{17}$ and because forced sales are generally disfavored..$^{18}$ However, in the event that the land cannot be divided practicably or without injury to the owners, the court may order a sale of the property and divide the proceeds among the owners. ${ }^{19}$

tition and take the unit as a whole in undivided possession. French Civil Code, Art. 815, amended by Laws of July 20, 1940, and January 15, 1943.

11 A thorough study of the question of the economic effects of partible inheritance would involve investigation into the number of private settlements among heirs as well as taking into account the vast number of unreported decisions. It is to be regretted that such information is so scarce. See note 22 infra. The number of reported decisions ordering sale are undoubtedly a small minority of the situations in which sale of jointly inherited land as a unit is achieved. They are helpful, thus, only in revealing the formal grounds upon which compulsory sale may be decreed or denied.

12 For a general discussion see 68 C.J.S., Partition $\$ 21$ (1950).

${ }^{13}$ E.g., N.Y. Civ. Pract. (Cahill-Parsons, 1955) c. 64, $\$ 1012$. The general procedure consists of a court appointment of commissioners to make actual division of the property. If the commissioners find that the land cannot be divided advantageously, a return so stating is filed with the court. Though the commissioners' report may be overruled by the court, it is ordinarily followed. Consult note 53 infra for an example of the substance of a commissioners' report.

14 'Property shall be partitioned by sale and division of the proceeds unless a party prays for partition in kind by its division into parcels, and shows that such partition is equitable and practicable. But personalty which is subject to any lien on the whole or any part can only be partitioned by sale." Iowa Code (1954) c. 651, R.C.P. 278.

${ }^{15}$ See Wolfe v. Stanford, 179 Okla. 27, 64 P. 2d 335 (1937).

16 E.g., Swogger v. Taylor, - Minn. -, 68 N.W. 2d 376, 384 (1955). (1942).

${ }^{17}$ See, e.g., Tuggle v. Davis, 292 Ky. 27, 29, 165 S.W. 2d 844, 845 (1942), 143 A.L.R. 1087

${ }^{18}$ See, e.g., Faires v. Pappmeier, 104 Cal. App. 2d 713, 232 P. $2 d 41$ (1951).

19 The Illinois provision is typical of the statutory grounds for sale: "When the whole or any of the premises sought to be partitioned cannot be divided without manifest prejudice to the owners thereof, and the commissioners appointed to divide the same so report, the court shall order the premises not susceptible of division to be sold at public vendue, upon such terms and notice of sale as the court directs." Ill. Rev. Stat. (1955) c. 106, §59. The general statutory breakdown is as follows: Thirty states and the District of Columbia allow a sale where prejudice, injury, damage, or detriment to the owners would result from partition in kind. Louisiana, Maine, Massachusetts, Vermont, Virginia, and West Virginia allow sale where the property cannot be conveniently or advantageously divided. Alabama, Arizona, Mississippi, and Texas permit a sale when a fair and equitable, or just and equal, division cannot be made. Kentucky, Ohio, and Wyoming prefer a sale where injury to the value of the property 
It is not altogether clear why there is any statutory preference at all. One factor may be a fear that a compulsory judicial sale might operate as a weapon of oppression against the cotenant who is unable to purchase the land at a time when land values are expected to rise. ${ }^{20}$ There may also be a feeling that if a sale was feasible it would have been consummated privately, or that the heir who wishes to retain a physical share of the land, perhaps for sentimental reasons, should be protected. ${ }^{21}$ Furthermore, the readiness with which courts have repeated the preference for partition in kind may be little more than a mechanical adherence to the doctrine of stare decisis.

Since a traditional preference exists for partition in kind the efficacy of compulsory sales in preventing undue fragmentation of land may not be readily apparent. It should first be observed that in actual practice it is customary for the heirs to transact sales in private settlements, in situations where a division would make farming impracticable. ${ }^{22}$ Where intestate property descends equally to the heirs as tenants in common, usually one heir is willing to buy out the others, ${ }^{23}$ or a third-party purchaser can be found, thereby preserving the original tract in either case. ${ }^{24}$ Because there is in the United States probably less

would result from physical division, and Kansas and Oklahoma specify a sale if injury would otherwise result, omitting any reference to injury to the owners or to the land (if there is any difference). In Pennsylvania a sale is warranted if physical partition would prejudice or spoil the whole. The Rhode Island statute leaves the matter to the court's discretion, but the leading interpretation, Lannon v. Lannon, 40 R.I. 60, 99 Atl. 819 (1917), states the statutory intent to be that a sale is proper where it is not practicable to make partition in kind. Furthermore, there is considerable overlapping of terminology among many of the statutes. For the Iowa statute, see note 14 supra.

${ }^{20}$ In Wolfe v. Stanford, 179 Okla. 27, 30, 64 P. 2d 335, 338 (1937), the court observed that much of the royalty from gas and oil lands was divided into small fractional interests, many of which were owned by persons of limited financial means. So conceivably upon the approach of development the right to partition might have been used as a means of foreclosing through sale the interest of the royalty owner of limited means; greatly enhanced value might have placed the property beyond his ability to elect to purchase or bid. Thus coercive judicial partition through sale might become a weapon of oppression and fraud in the hands of the financially fortunate. As a result the court suggested that in the presence of approaching development or rapidly increasing values, inability of a cotenant to purchase might constitute a defense. Ordinarily such inability is not a defense; see infra note 41 .

${ }^{21}$ In private agreements an arrangement could be made by which the recalcitrant heir might retain a physical share while the remaining collective interests could be sold. This technique of partial sale is difficult to achieve in most courts. But for an instance where a partial sale was allowed consult Swogger v. Taylor, - Minn. -, 68 N.W. $2 \mathrm{~d} 376$ (1955).

22 There is a surprising and unfortunate paucity of statistical information on private settlements in the United States. However one very thorough and worthwhile study of a small Nebraska farm community was made by Robert E. Diller, op. cit. supra note 7, which contains, among other things, much interesting data on the relationship of inheritance and land ownership. No comparable study on a wider basis was found.

28 Johnson and Barlowe, op. cit. supra note 4, at 287.

${ }^{24}$ Even though private sales are common, they are not without some disadvantages. For one thing, if an heir wishes to buy out his coheirs he must usually mortgage the farm, and the consequences of heavy mortgaged-indebtedness can be severe. U.S. Dep't Agriculture, Soils 
attachment to the soil ${ }^{25}$ than in many parts of the world, psychological barriers to the relinquishment of land are minimized. Economic factors, thus, have comparatively more free play, ${ }^{26}$ consequently facilitating sales. The problem of division rarely exists in the uncommon situation where the farmer-parent dies testate, in which case the land is frequently devised either to the widow ${ }^{27}$ or to a specific heir.

Statutes have defined almost no criteria to aid the courts in determining whether the requisites for a sale have been satisfied. ${ }^{28}$ The courts, however, have evolved one criterion which has now become the general test:

[T] he "generally accepted test of whether a partition in kind would result in great prejudice to the owners is whether the value of the share of each in case of a partition would be materially less than his share of the money equivalent that could probably be obtained for the whole." 29

and Men, Yearbook of Agriculture 118 (1938). Also, the purchasing heir may have to go above the open market price because the heirs are likely to attach a sentimental value to the farm. Ibid. It has been suggested that governmental assistance in the purchase of farms be given to the heir who wants to retain the family land but cannot finance the purchase with the aid of a "safe" first mortgage. Diller, op. cit. supra note 7, at 54 .

${ }^{25}$ One aspect of this characteristic is the considerable mobility and urban-migration of the rural population. It has been estimated that from 1920 to 1930 well over six million people migrated from farms. Baker, Rural-urban Migration and the National Welfare, in Annals of the Association of American Geographers 87-89 (1933). Among the reasons advanced in explanation of the migration trend to cities are increases of farm population combined with decreased need of farm manpower because of mechanization, and potentially larger earnings in urban areas. Kolb and Brunner, op. cit. supra note 7, at 221-222. The lack of sufficient historic opportunity to develop a deeply-rooted family attachment to the soil undoubtedly helps to account for the great mobility factor. In this regard, the tradition in American history of "moving on" to a new frontier should probably also be considered. For the latter, see the writings of Frederick Jackson Turner.

${ }^{25}$ That farmers characteristically share, to some considerable extent, the commercial nature of American society is commonly pointed out by expert observers. Thus, in a sociological study it was said that the farmer has been converted into "something of a speculator and mercantilist." Kolb and Brunner, op. cit. supra note 7, at 263. And Diller, op. cit. supra note 7, at 132 , noted in his study that in a time of falling land values there is a widespread reluctance to make private sales and an increase in tenancies, while in more prosperous times land is readily sold.

${ }^{27}$ In Diller, op. cit. supra note 7 , at 39,47 , it was found that a substantial amount of land was held by widows, most of whom did not farm, and consequently the land was customarily leased.

${ }^{28}$ In Kirk v. Head, 132 S.W. 2d 125 (Tex. Civ. App., 1939) the court complained that no yardstick had been provided to determine the quantum of proof necessary to enable courts to find whether or not a fair and equitable division could be made.

28 Trowbridge v. Donner, 152 Neb. 206, 214, 40 N.W. $2 d$ 655, 660 (1950). This ground for authorizing a sale has been accorded statutory mention in some states. The Louisiana statute, after providing for a sale when property cannot be conveniently divided, adds, "It is said that a thing can not be conveniently divided, when a diminution of its value, or loss or inconvenience of one of the owners, would be the consequence of dividing it." La. Stat. Ann. Civil Code (West, 1952) $\$ \$ 1339,1340$. Compare with Ariz. Code Ann. (1939) c. 27, $\$ 1308$, and Ga. Code Ann. (1955) c. $85-15, \$ 85-1511$, both of which mention the possibility of sale where actual partition would depreciate the value of the property. Further, this ground would seem 
Over-fragmentation must result in a depreciation of the value of the sum of the divided parts. Thus, when courts decree sales in order to prevent the depreciation in value of land which would result from partition, the size of the original tract is preserved and the need for land reform resulting from partible inheritance is obviated.

An obvious case for sale is present where a tract of land is jointly owned by so many persons as to render each individual share too small to be suitable for the type of use to which the land is most adaptable. For example, in Snyder v. Snyder, ${ }^{30}$ four cotenants owned a sixty-acre farm, three heirs each owning an interest of one-eighth and the fourth owning an interest of five-eighths. In upholding a sale in a suit by the owner of a one-eighth interest, the court said:

[I] the farm were divided into $7 \frac{1}{2}$-acre tracts, it would greatly depreciate the value of the farm sold as an entire tract. The farm is too remote from any urban population to appeal to purchasers of acreage tracts. It is at once apparent that such a division would greatly depreciate the value of the interests of the respective owners of these undivided fractional shares. It is at once apparent that, if such a division were ordered, the fencing of each separate tract would be necessary, and if so divided, it would leave the owners with small tracts that would not be suitable for agricultural purposes. ${ }^{31}$

In cases involving urban land, lots are invariably smaller than rural tracts, and decrees of sale are very common. ${ }^{32}$ The Kentucky courts have gone so far as to adopt a presumption that town lots are not susceptible to advantageous division by partition in kind, ${ }^{33}$ thereby displacing the traditional contrary statutory preference.

to be implicit in at least Ohio, Kentucky, and Wyoming, where statutes authorize a sale if injury to the value of the land would otherwise result. Ohio Rev. Code and Serv. (Baldwin, 1953) c. 53, §5307.09; Ky. Codes (Carroll, 1948) §494(7); Wyo. Comp. Stat. (1945) c. 3, $\$ 3-6909$.

${ }^{30} 211$ Iowa 445, 233 N.W. 498 (1930). This case was decided long before the statutory presumption had been changed. Consult pp. 350-51 infra.

${ }^{31}$ Ibid., at 446, 498. Consult, for further examples, White v. Smyth, 147 Tex. 272, 214 S.W. 2d 967 (1948) (sale of large tract of rock asphalt); Murphy v. Bates, 224 Iowa 389, 276 N.W. 29 (1937) (sale of farm divided by roads into three irregularly-sized tracts, the three portions widely differing in value); Brown v. Cooper, 98 Iowa 444, 67 N.W. 378 (1896) (sale of property by a river, the court noting the variability of the flow of water); Branscomb v. Gillian, 55 Iowa 235, 7 N.W. 523 (1880) (sale of farm because the value of all the divided shares would be less than the value of the tract as a whole).

32 E.g., Oziah v. Howard, 149 Iowa 199, 128 N.W. 364 (1910); Muller v. Muller, 14 Cal. App. 347, 112 Pac. 200 (1910); Phillips v. Phillips, 185 Ill. 629, 57 N.E. 796 (1900); Greenup v. Sewell, 18 Ill. 50 (1856). In the latter case the lot in controversy was fifty feet in width, situated in Nashville, Illinois. The court said, at 51, that "to divide the lot . . . would reduce the relative value of the remainder, if it would not render it utterly unsaleable. When such is the case ... the property should be sold and the proceeds divided." In the Phillips case, supra, at 632,798 , the property after division would have consisted of residential lots in a Chicago suburb $18 \frac{3}{2}$ feet wide and 600 feet running back from the street. According to the court, "[I]t is common knowledge there is no possible use or sale for a village lot of such dimensions."

${ }^{33}$ E.g., Fannin v. Fannin, 256 Ky. 273, 75 S.W. 2d 1042 (1934). 
Judicial sales are most prevalent, though, in cases of mineral lands, particularly of oil and gas, because the uncertainty as to the location, extent, and value of the minerals would render a fair physical division impossible. ${ }^{34} \mathrm{It}$ is primarily when the mineral lands are completely unprospected that partition in kind may be awarded. ${ }^{35}$ Finally, certain types of property have been accorded special statutory treatment. For example, in one state standing timber is made subject to sale at the request of any one owner. ${ }^{36}$

In addition to diminution of value, other factors are considered which might render the land practicably or physically indivisible, such as differences in elevation of the land ${ }^{37}$ or inaccessibility of some portions of the land to highways and streams. ${ }^{38}$

When a sale is ordered it is very common for a cotenant to purchase the land, ${ }^{39}$ and in some states he is allowed to purchase before the land is offered at public sale. ${ }^{40}$ The fact that any cotenant is financially unable to purchase the entire tract does not operate as a defense against a petition for sale. ${ }^{41}$ The

34 Consult, generally, Right to Partition in Kind of Mineral or Oil and Gas Land, 143 A.L.R. 1092 (1943).

$$
{ }^{35} \text { Ibid., at } 1101 . \quad \quad{ }^{36} \text { N.C. Gen. Stat. (1950) c. 46, } \$ 25 .
$$

${ }^{37}$ Smith v. Norton, 206 Okla. 422, 243 P. 2 d 980 (1952).

${ }^{38} \mathrm{Ibid}$. In this case it was also noted that the tract in question was useful for municipal subdivision purposes, though at the time it was used for pasture. Further, in considering whether partition in kind would be practicable, the location of improvements upon the land is often important. Hoss v. Hardeman, $156 \mathrm{La}$. 371, 100 So. 532 (1924). Again, in a most unusual decision a sale was decreed on the ground that a physical division of a tract used for a tourist attraction would injure the parties because the cotenants would become competitive rivals for profits. Briges v. Sperry, 95 U.S. 401 (1877). This case is discussed infra note 44.

${ }^{39}$ Consult page 346 supra.

40 E.g., Ohio Rev. Code and Serv. (Baldwin, 1953) c. 53, $\$ 5307.09,5307.11$; Kan. Stat. Ann. (1949) c. 60, $\$ \$ 2110,2111$; Wyo. Comp. Stat. (1945) c. 3, \$ 3-6909.

41 In Hayne v. Gould, 54 Fed. 951,961-62 (C.C. Calif., 1893), rev'd on rehearing on other grounds, 54 Fed. 963 (1893), plaintiff was a western farmer who owned an undivided one-half interest of a large olive ranch along with the defendant, a New York lawyer. Plaintiff worked the ranch and defendant supplied some capital. Apparently both parties originally had contemplated eventual sale. The court awarded partition in kind, sought by plaintiff, on the ground that the ranch was capable of division in kind. In the course of its opinion, the court stated, "[T] he mere contemplation of the parties in respect to the venture into which they entered is not sufficient . . . to deny . . . a partition of the property. . . . [T] hat the defendant is ... in a distant state, and has no practica! knowledge of ... olive culture, is unimportant, as is the pecuniary inability of the plaintiff to buy the property in the event it should be directed to be sold as a whole. The situation of the property, and not the personal circumstances of the parties, unconnected with their interests therein, is the question that must control the court in determining whether there should be a division or sale of the property."

But see Wolfe v. Stanford, 179 Okla. 27, 64 P.2d 355(1937), note 20 supra, for dictum posing one situation wherein financial inability to purchase the entire tract might constitute a defense, contrary to the acknowledged general rule.

In Tibbs v. Allen, 27 Ill. 118 (1862), the impoverished heirs were not defending but seeking a sale; however, the court ordered partition in kind. The tract in controversy contained 720 unimproved acres in Springfield, Illinois which yielded no income but the sale of which would have brought a substantial amount. 
pecuniary condition of the parties is sometimes considered by the courts, but only when partition in kind might require a payment of owelty ${ }^{42}$ (that is, an amount assessed against one party to equalize the partition shares) and not when asserted as a defense to a sale. Furthermore, other personal circumstances of the parties as they might relate to the land are usually not considered, such as ownership by one cotenant of land adjoining the tract in controversy. ${ }^{43}$ An occasional case demonstrates departures, however, and considers the personal situations of the parties. ${ }^{44}$

In the absence of a showing of the necessity of a sale, partition in kind will be awarded as a matter of right. ${ }^{45}$ But once a party sustains the burden of proving the necessity of a sale, the original presumption for partition in kind is not only rebutted but the sale becomes a matter of absolute right. ${ }^{46}$ Thus upon proof that the property cannot be conveniently or advantageously divided in kind, sale becomes a simple matter as any cotenant is entitled to a compulsory sale notwithstanding the objections of other cotenants. ${ }^{47}$

In the light of the above considerations it is at once apparent that the statutory presumption may have little, if any, substantive effect. The draftsmen of the present Iowa provision, ${ }^{48}$ which alone reverses the traditional statutory presumption, clearly indicated that the new provision only conformed to practice:

42 For an example of the owelty situation, consult Lannon v. Lannon, 40 R.I. 60, 99 Atl. 819 (1917).

${ }^{43}$ In Todd v. Stewart, 199 Iowa 821, 202 N.W. 844 (1925), the court stated that the fact that one cotenant owned land adjoining the lot in controversy, thereby making one part of the latter lot especially valuable to him, did not necessarily require a physical partition. But cf. Bridge v. Snead, 151 Va. 383, 145 S.E. 338 (1928), wherein ownership of an adjoining lot did influence the court in its award of partition in kind; however, no satisfactory grounds for sale had been presented to the court.

44 In Briges v. Sperry, 95 U.S. 401 (1877), note 38 supra, the parties jointly owned two large tracts, a few miles apart, operated as very successful tourist attractions. In ordering a sale, the court considered the potential competitive situation of the parties in noting that the value of the property would be injured if split up into portions held by rivals for profit. A hotel stood on one of the tracts, making equal partition in kind difficult; though this difficulty could have been met by a payment of owelty, the court expressly set aside that possible solution. Furthermore, in rationalizing the decision the court mentioned the inequality of the owners' shares as a serious difficulty; but this may be doubted because there were but three main shares and the tracts were large.

${ }^{45}$ See, e.g., De Roulet v. Mitchel, 70 Cal. App. 2d 120, 160 P. 2d 574 (1945).

46 "The right to sell for division is conditioned upon averment and proof that the property cannot be equitably divided in kind. When this condition appears the right to sell for division is a matter of right." Chambliss v. Derrick, 216 Ala. 49, 51, 112 So. 330, 332 (1927), approved in Littledale v. Brush, 240 Ala. 566, 200 So. 411 (1941). For further examples see De Roulet v. Mitchel, note 45 supra, and Baumgartner v. Baumgartner, 17 Tenn. App. 305, 67 S.W. 2d 154 (1933).

47 De Roulet v. Mitchel, 70 Cal. App. 2d 120, 160 P. 2d 574 (1945).

${ }^{48}$ The provision, Iowa Code (1954) c. 651, R.C.P. 278, was drafted by an Advisory Committee of the Iowa Bar Association for inclusion in a body of recommended rules of civil procedure, which were submitted to the state supreme court along with comments, and recommended by that body to the legislature. The recommendations were subsequently enacted in Iowa Gen. Assemb. c. 278, § 278, p. 342, 50th Gen. Assemb. Reg. Sess. (1943). 
Under Code 1939, $\S 12326$, it is provided that the property shall be partitioned in kind unless it appears that the property cannot be equitably divided. Under section 12327 , it is provided that three referees shall be appointed to make partition unless it is shown that the property cannot be divided. In practical operation a partition in kind is a rarity. This Rule does not change the substance of the present statutory provisions, but it does change the emphasis. Under it, if neither the plaintiff or any defendant wants partition in kind, the court need not concern itself with that phase. If any party wants partition in kind, it is up to such party to make a prima facie showing as to its practicability. [Emphasis added.] ${ }^{49}$

It may well be that the same result is attained, in fact, in the other jurisdictions adhering to the traditional presumption. The same economic factors that affect private settlements will be considered by the courts; that is, injury to the value of the land. And if injury will result from physical division, a judicial sale becomes a matter of right, completely displacing the traditional preference for partition in kind, and it is the character of the land and not the personal situation of the parties that is determinative of a sale.

Although it is relatively simple to demonstrate the necessity of a sale in cases of mineral lands, ${ }^{50}$ town lots, ${ }^{51}$ and small farm holdings, ${ }^{52}$ proof is more difficult in cases of larger farms. In cases involving agricultural land, courts usually decree partition in kind, but no case was discovered where partition in kind was awarded when it was shown that harm would result from parcellation of the land. ${ }^{53}$ And where parcellation does not injure the value or efficiency of the land, there is no problem of land reform arising from partible inheritance.

It would seem that the system of partible inheritance need not result in the undue fragmentation of land. If any cotenant can prove that physical division would decrease the value of the separate parts by rendering the land unusable or less efficient, he may compel a judicial sale as a matter of right. Considered with the present operation in the United States of ordinary economic factors in encouraging private settlements, the machinery for compulsory judicial sales appears to be currently adequate to prevent any economic ill effects that might otherwise result from the institution of partible inheritance.

19 Comment of the Advisory Committee, Iowa Bar Ass'n., Letter dated October 5, 1955, from Charles W. Barlow, Iowa Code Editor and Supreme Court Reporter, in the University of Chicago Law School Library. This comment stands as the only indication of the reasons for the change.

${ }^{50}$ Consult page 349 supra. $\quad{ }^{31}$ Consult page 348 supra. $\quad 52$ Consult note 31 supra.

53 Commissioners may advise that in certain situations partition in kind would injure the value of farm land. In Bridge v. Snead, 151 Va. 383, 386, 145 S.E. 338, 339 (1928), the plot in controversy was thirty-one acres in undivided shares of three-fifths, one-fifth, and one-fifth. In making a report, the commissioners wanted "to give ... reasons for thinking the land divided physically into five equal parts would not be worth as much in the aggregate as if it were undivided and sold. The several parcels would be so small that none of them would contain sufficient ground to justify anybody buying it as a home and having enough ground to farm." However, in this case the court refused to follow the commissioners' report on the ground that the land only had to be divided into three parts, not five, and there was not sufficient evidence that the sum of the value of the three parts would be less than the whole. 